
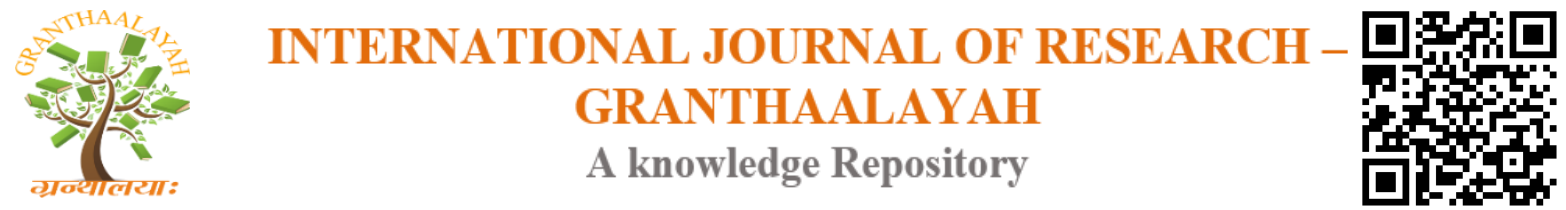

Science

\title{
THE DECEMBER 2013 WEATHER IN SOUTHEAST NIGERIA: WHAT DO STAKEHOLDERS THINK?
}

\author{
Robert Ugochukwu Onyeneke ${ }^{1}$, Chinedum Uzoma Nwajiuba ${ }^{1}$ \\ ${ }^{1}$ Department of Agriculture, Alex Ekwueme Federal University Ndufu-Alike, Ebonyi State, \\ Nigeria
}

\begin{abstract}
This study documented stakeholders' perception on the changing rainfall pattern in southeast Nigeria. The paper collected data from many stakeholders across Nigeria. Stakeholders' view about changing rainfall pattern using the December 2013 event was presented. Most of the stakeholders attributed the increasing number of rainy days in December 2013 to climate change. The stakeholders also believed that this new rainfall pattern will impact on different economic sectors and activities. Various adaptation strategies were recommended as the way to manage the risks that may accompany the recent rainfall pattern.
\end{abstract}

Keywords: Rainfall; Variation; December 2013; Stakeholders.

Cite This Article: Robert Ugochukwu Onyeneke, and Chinedum Uzoma Nwajiuba. (2019). "THE DECEMBER 2013 WEATHER IN SOUTHEAST NIGERIA: WHAT DO STAKEHOLDERS THINK?." International Journal of Research - Granthaalayah, 7(7), 132-142. https://doi.org/10.29121/granthaalayah.v7.i7.2019.739.

\section{Introduction}

Conventional classification of the weather in most of southern Nigeria places the area as rainforest. By this there are two broad classifications, which are the rainy season and the dry season. The rainy season commences in most parts of southern Nigeria around April and last till October. The dry season commences around November and ends March. This however does not imply a total absence of rainy days in the dry season months.

December can be taken as the usual peak of the dry season. Conventionally the Harmattan is what often occurs in December. Nevertheless in some years, a few days in December could have rains. Between 1972 and 2012 (forty one years), there were rains recorded at the National Root Crops Research Institute (NRCRI) Umudike in Abia State in Southeast Nigeria in December. The most important was in 1983 with 6 days of rain and a total of 25.9 millimetres (Table 1). The NRCRI is the most important research institute in southeast Nigeria and has the longest history of recorded weather parameters. 
Table 1: December 2008 - 2012 Rainfall amount in Millimetres (MM) and Rainy Days at Umudike (Latitude $05^{\circ} 29^{\prime} \mathrm{N}$, Longitude $07^{\circ} 33$ 'E, Altitude 122MM Above sea level)

\begin{tabular}{|l|l|l|}
\hline Year & Rainfall & Rainy Days \\
\hline 1972 & 14 & 1 \\
\hline 1973 & 6.27 & 4 \\
\hline 1974 & 1 & 1 \\
\hline 1975 & 16.2 & 1 \\
\hline 1976 & 12.3 & 1 \\
\hline 1977 & 0 & 0 \\
\hline 1978 & 4 & 1 \\
\hline 1979 & 1 & 0 \\
\hline 1980 & 0 & 0 \\
\hline 1981 & 0 & 0 \\
\hline 1982 & 14.4 & 1 \\
\hline 1983 & 25.9 & 6 \\
\hline 1984 & 0 & 0 \\
\hline 1985 & 11.1 & 2 \\
\hline 1986 & 0 & 0 \\
\hline 1987 & 0 & 0 \\
\hline 1988 & 6.9 & 1 \\
\hline 1989 & 0 & 0 \\
\hline 1990 & 35.3 & 4 \\
\hline 1991 & 26.2 & 2 \\
\hline 1992 & 0 & 0 \\
\hline 1993 & 15.7 & 2 \\
\hline 1994 & 0 & 0 \\
\hline 1995 & 21.8 & 1 \\
\hline 1996 & 0.7 & 1 \\
\hline 1997 & 22 & 3 \\
\hline 1998 & 2.6 & 1 \\
\hline 1999 & 0 & 0 \\
\hline 2000 & 3.8 & 2 \\
\hline 2001 & 0 & 0 \\
\hline 2002 & 0 & 0 \\
\hline 2003 & 0 & 0 \\
\hline 2004 & 5.1 & 1 \\
\hline 2005 & 8.6 & 2 \\
\hline 2006 & 0 & 0 \\
\hline 2007 & 25 & 2 \\
\hline 2008 & 8.9 & 1 \\
\hline 2009 & 0 & 0 \\
\hline 2010 & 4.6 & 1 \\
\hline 2011 & 9.6 & 1 \\
\hline 2012 & 0 & 0 \\
\hline & & \\
\hline
\end{tabular}




\section{The Issue}

The experience in December 2013 is that there have been at least six days of rains in most states of the southeast. This has generated interest by people in the region. Many are asking questions and many are bothered by the consequences of such extreme weather event. The observations so far is that the rains from Saturday December 7 to Friday December 13 have been virtually daily, in some cases lasting up to nine hours (in Owerri, Imo state on Wednesday December 11 rain started at about $1 \mathrm{pm}$ and lasted till $10 \mathrm{pm}$ ), with occasional thunder sounds and lightning. Unfortunately we have not been able to find a rain gauge functioning anywhere in Owerri in this period despite the existence of several tertiary institutions engaged in the study of environmental and related subjects. We therefore obtained readings from the NRCRI Umudike up till December 11, 2013. This is presented in Table 2. It can be seen that as at December 11, five days of rain has so far been recorded.

Table 2: December 2013 Rainfall amount in Millimetres (MM) and Rainy Days at Umudike (Latitude $05^{\circ} 29^{\prime} \mathrm{N}$, Longitude $07^{\circ} 33$ 'E, Altitude 122MM Above sea level)

\begin{tabular}{|l|l|}
\hline Date & Rainfall \\
\hline December 2 & 2.8 \\
\hline December 5 & 5.3 \\
\hline December 7 & 0.8 \\
\hline December 10 & 23.1 \\
\hline December 11 & 48.3 \\
\hline
\end{tabular}

Source: NRCRI Meteorological Unit Umudike, Abia State, Nigeria

To be able to provide informed advice we need reliable dat. This may be lacking. We however proceed to improvise and answer questions such as what are the consequences of this atypical rainfall experience.

\section{What Can We Expect?}

Reflecting on the statistics shown in Table 1, it can be seen that closest to this kind of phenomena is the 1983 scenario. This suggests that whatever consequences which researchers, farmers, environmentalists and other stakeholders may anticipate we may learn from what followed the 1983 experience. We may therefore be interested in what happened with the agricultural sector in the years following, which are 1984 and 1985 (Table 3). Table 3 shows yam, cassava and cocoyam production in Imo state in the period of interest. These statistics are for Imo state and sourced from the Imo State Accelerated Development Area Programme (ISADAP). Note that in the period 1983 to 1995, the present Abia state where the NRCRI is located was part of Imo state. Abia was created in 1991. The statistics in Table 3 therefore refers to Imo and Abia states.

Table 3: Output of some selected crops in 1983, 1984 and 1985 in thousand Metric tons

\begin{tabular}{|l|l|l|l|}
\hline Year & Yam & Cassava & Cocoyam \\
\hline 1983 & 191,000 & 293,000 & 13,000 \\
\hline 1984 & $1,079,311$ & 204,577 & 65,615 \\
\hline 1985 & $1,056,698$ & 201,896 & 77,130 \\
\hline
\end{tabular}

Source: ISADAP (2008) 
Assuming the reliability of the statistics in Table 3, can we expect that all things being equal, output of major crops such as yam and cassava, and minor crop such as cocoyam may increase in 2014 and 2015? This we may not be able to do without a multi-variable study of the determinants of the output of those crops in Imo state. We can reasonably expect that climate is only one variable, although very critical variable, in the rainfed dominant farming systems of Imo sate and the southeast. This justifies the need for a study of the farm level impact of the observed weather regime this December 2013.

\section{What is the Extent of this Phenomenon?}

To be able to provide some informed position on this extreme rainfall experience for the month of December in southeast Nigeria, we reached out to researchers and other persons interested in the subject across Nigeria, but with emphasis on southeast Nigeria. From the responses it became obvious that for the period December 7 to December 13, 2013, this event was observed in Calabar in Cross River state, Uyo in Akwa Ibom state, Portharcourt in Rivers state and Umudike in Abia state. The intensity was less in Enugu, slightly more in Abakiliki, and less in Asaba in Delta state and Benin in Edo state. Locations in the southwest such as Ibadan in Oyo state and Ado-Ekiti in Ekiti state, and then Ilorin in Kwara sate and Anyagba in Kogi state, both in North Central Nigeria were not affected but observed clouds and occasional drizzles. Abuja the Federal Capital was reported as dry. This phenomenon seems therefore to have concentrated in the southeastern coastal, mangrove and rainforest areas.

\section{What do the Experts Say?}

We subsequently reached out to 65 experts in environmental and related stakeholders for their perception and opinion on the observed rainfall regime for December 2013, and likely consequences. Their responses follow:

[1] Expert 1 (in Lagos) - Academic: It feels like we are in the rainy season but the Island experiences far less rain than mainland where it truly rains very heavily and has done so for days.

[2] Expert 2 (in Owerri) - Academic: The likely consequences of the unusually rainfall in southeast are increase in postharvest losses, change in cropping pattern/timing, lack of enough dry/ harmattan period that breaks the dormancy in trees will adversely affect fruiting, reduction in soil fertility through leaching, reduction in local seasonal trade volume, dilapidation of roads, delay in infrastructure development, and increase in the number of erosion sites

[3] Expert 3 (in Owerri) - Academic: This is very worrisome and unusual. Climate change is here with us. We were discussing this strange rainfall pattern in my house last night (111213). The consequences are no harmattan, loss of critical habitats and vital ecosystems, and famine and pandemonium

[4] Expert 4 (in Aba) - Health worker: There has been torrential rain in Aba. Humanly speaking we will say it is climate change but spiritually there is a prophecy as regards to it. This pointing to end. How I wish others (Christians) will notice it. May God help us to understand what it means.

[5] Expert 5 (in Owerri) - Academic: It is hard to come to terms that the SE and SS has become the high rainfall zone of the country. I have been in is Asaba for days now and there has been no rain. Climate change. The implications will be grave. There will be scarcity of mist fruits such as ube (Dacryodes edulis) mango (mangifera indica), etc. And some food crops. 
This is because the harmattan wind that brings about the pollination of flowers will be truncated. It is serious.

[6] Expert 6 (in Owerri) - Academic: It will hamper the following: the construction industry, such as road construction, agriculture especially harvesting and storage, the environment, example increased flash flooding, and local commerce for example drop in Christmas sales and more. I think it will affect intensity of this year's harmattan.

[7] Expert 7 (in Umuahia) - Academic: At the face value, one would look toward all year round cropping because irrigation is replaced by rains. My fear is the possible emergence of virulent flora and fauna that could present challenges to man just as HIV.

[8] Expert 8 (in Abuja) - Legislator: The variations in pattern in my lay man's point to climate change.

[9] Expert 9 (in Abeokuta) - Academic: It is not raining in Ogun state.

[10] Expert 10 (in Owerri) - Academic: A very large aberration, but not yet protracted. If it continues, the consequences will be pronounced for agriculture, forestry wildlife, hydrology, etc. Examples are plants that require long dry season for flowering will produce less fruits and those that hate it will do better. Wildlife that has moved out or started to move may return or stay put. Streams like Okitankwu will not dry out as before and riparian vegetation will continue blooming as if the rainy season hasn't ended. Cultivation will start or continue in earnest. The much dreaded/loved harmattan and its accomplishments will sharply decrease or totally disappear.

[11] Expert 11 (in Lagos) - Engineer: We have had two heavy rainfall in the afternoon as if it were in the rainy season.

[12] Expert 12 (in Owerri) - Academic: Contractors building seasonal roads will count their losses. Postharvest losses may be high in tuber crops. Flood disaster is a common feature. Flowering and fruiting of tree crops may be interrupted. Social and economic activities are adversely affected this season, etc.

[13] Expert 13 (in Abakaliki) - Academic: The rain may not be divorced by climate variability. We need some data to confirm.

[14] Expert 14 (in Benin) - Federal Ministry of Agriculture: The daily rainfall continued yesterday (Thursday December 12) in Benin. The rain has been on since Friday December 6. It has been a daily affair in Benin City and around Edo state up to December 11. The heaviest was on Saturday December 7. Consequences are reduction in yields for crops whose flowering/fruition depend on the cool dry season dew/moisture. This may lead to higher prices, greater food insecurity and prevalence of poverty. If the trend continues, farm calendars, and agricultural practices will be altered.

[15] Expert 15 (in Minna) - Academic: The last rain recorded in Minna was in October. There was no rain in November 2013. The unusual rains in the South are occasioned by global warming. Consequences are imminent flood, adverse effect on farming incomes and livelihoods. It will affect planning and policy.

[16] Expert 16 (in Ibadan) - Development Practitioner: It has only drizzled twice. Just yesterday (Wednesday December 11) it rained heavily for 2 minutes and showered for another 5 minutes. It was the same all over Ibadan.

[17] Expert 17 (in Onitsha) - Religious Leader: We started seeing it on Sunday (6 $6^{\text {th }}$ December) evening. I am worried that the season seems not to be working. I believe we are in the last days. May God have mercy on us. 
[18] Expert 18 (in Makurdi) - Academic: This is really strange. Think climate change is at work. There was no rain until last night (Wednesday December 11).

[19] Expert 19 (in Abakaliki) - Academic: The climate is changing and the equilibrium of most climate, ecological and anthropogenic determinants are being distorted to the extent of threats to human life and existence.

[20] Expert 20 (in Port Harcourt) - Community Member: In the past the harmattan came on or before December 15. Surprisingly the rain is falling on a daily basis in Rivers state. The people here are complaining.

[21] Expert 21 (in Owerri) - Academic: Infection cycles of pests and pathogens are altered due to premature release of propagules and other infection structure from their dominant states due to the timing, duration and intensity of the rains. Disease prediction is seriously jeopardised.

[22] Expert 22 (in Abuja) - Federal Ministry of Agriculture: If the rainfall pattern this December is not typical, then there is obviously nothing to worry about. NIMET warned earlier that there could be extended rains towards the end of the year, and that is probably what is beginning to happen. The persistence and severity will determine the nature and level of challenges it will pose.

[23] Expert 23 (in Ado-Ekiti) - Academic: There was heavy rain on Saturday night and a light one Sunday evening in Ado-Ekiti.

[24] Expert 24 (in Uyo) - Academic: We have not been having rain, not to mention heavy rain in December. But it has been raining heavily. This is not normal in Uyo.

[25] Expert 25 (in Asaba) - Community member. On and off, very unusual but then we have climate change.

[26] Expert 26 (in Ikeduru) - Religious Leader: I have not witnessed this before. I told someone today that it would be expedient to plant maize because this will affect agriculture. Flooding is inevitable. The stormy wind in some areas is devastating already. It calls for proactive steps by individuals, communities and government and your question awakens the consciousness of this climate change and its adverse effects.

[27] Expert 27 (in Ilorin) - Academic: The situation depicts a change in the well established climatic pattern (where there are rainy and dry seasons or the so called climate change. It will impact on food production, supply and availability. For instance yam that are buried in the ground or stored in barns on the field might start to germinate while a change in planting, maturity and harvesting period for most crops will impact on food supply. This is apart from other changes in livelihood patterns that can arise as a result of the climate change. It rained lightly in Ilorin few minutes ago (Friday December 13).

[28] Expert 28 (in Abakaliki) - Academic: Your question has kept me pondering for 2 days. The likely consequences could be the rain stopped earlier than when it is supposed to but still heavy in the sky. The harmattan will be more sever this year. There will be more food this coming farming season.

[29] Expert 29 (in Abuja) - Federal Ministry of Environment: In the tropical rain forest belt, rainfall has the right of way any time. There is no cause for alarm. We are dry here in Abuja.

[30] Expert 30 (in Jalingo) - Pharmacist: Climate change is continuously advancing. Unlike 40 years ago when the grassy vegetations in the village in Imo State were very dry by now and can easily burn as we work on the traditional roads. The consequences are that local storage of tuber crops like yam and cocoyam may be risky due to spoilage. Microbial 
balance of the soil may be altered. Overall local vegetation and insect species may be affected negatively or positively. How we guide against these is a research challenge.

[31] Expert 31 (in Umuahia) - Academic: the consequences of the prolonged rains in southeast Nigeria are late arrival of harmattan and absence of dust, reduction in number of soil nitrogen fixing microbes, prolonged floods on rural roads, poor storage of grains due to high microbial, long term fall of acid rains and soil acidification and decline in nutrients, and then reduction in yield of fruit trees.

[32] Expert 32 (in Owerri) - Academic: Your observations are quite in order. A possible change in the duration of the rainy season because the grasses in my garden are still lush green. Delayed harmattan, does not augur well for auspicious farm harvesting, we are spared the usual rain of red dust about this time.

[33] Expert 33 (in Owerri) - Academic: The same in Portharcourt today (Wednesday December 11), even last Sunday, December 8 in Portharcourt with heavy thunder. I wondered why. With much flood that the soil cannot absorb. There is a problem somewhere but meteorologists should tell us. There will be longer harmattan period which will foster much fruiting of plants next year

[34] Expert 34 (in Owerri) - Academic: The consequences would be positive and negative. On the positive side there would be continued production of vegetables and fruits consequently that would lower prices. Then on the negative side there would be flooding in some parts of the state and our vehicles will suffer, mechanics will be very happy because they will enjoy Christmas at our expense.

[35] Expert 35 (in Ihitte/Uboma) - Farmer: Climate change is the issue at stake. The case of Nigeria is what you have been saying all along. Therefore here comes climate change. No one can change climate. Education is required.

[36] Expert 36 (in Owerri) - Academic: This is a manifestation of climate change, causes, consequences and mitigation. We are even lucky not experiencing earthquakes and other environmental calamities. For pregnant women this is favoured weather compared to heat.

[37] Expert 37 (in Uyo) - Non-Governmental Organization: This may be due to extreme changes in climatic conditions, which is likely attributed to negative and positive feedback of climate change impact like emission of $\mathrm{CO}_{2}$ and other anthropogenic causes that increase the impact of climate change in our environment.

[38] Expert 38 (in Owerri) - Academic: This phenomenon is changes in rainfall pattern and rainfall variability which are attributed to global warming which alters weather elements.

[39] Expert 39 (in Owerri) - Religious Leader: We discussed it also in our meeting as it rained heavily her today (December 11) too. I think we will have severe harmattan this year and more farm food next year. It is an act of merciful God who controls the universe. To Him be glory.

[40] Expert 40 (in Owerri) - Academic: the abnormal December rainfall is extreme weather event. The climate change signature tilts to more rain now. Soon, we will have drought signature of climate change.

[41] Expert 41 (in Owerri) - Religious Leader: Who knows? What I know is that the same God who makes water out of a dry land can also give rain in dry season. This may cause us to have late rain next year and planting may be delayed. Yet I am not afraid for my guess may not be right. Only God has the answer.

[42] Expert 42 (in Bauchi) - Academic: This is really strange. One is tempted to think our usual culprit, climate change. 
[43] Expert 43 (in Owerri) - Academic: There are major variations between July conditions and the current conditions. First the relative humidity during the typical July season is different from current conditions. Secondly the volume of precipitation is obviously lower than July conditions. There is no doubt that there is similarity in the periodicity in terms of number of concurrent days of rain. Likely consequences are prolonged hamattan in December and January.

[44] Expert 44 (in Owerri) - Ministry of Agriculture: The migratory birds have not returned. The rice fields are still green but well filled. Cassava diseases and tuber rot are few. It will affect flowering of fruit trees like ube, mango, guava (Psidium guajava). Quantity will be less in April and May. With the rain there will be plenty of ugu and green vegettable (telferia) in December and January. Diseases like blast in rice and mealybug of cassava will be less. Bush burning for early planting in January wild fire will be less. On the side of livestock, green grass will be available and animal diseases especially local fowl less.

[45] Expert 45 (in Owerri) - Academic: How best do we describe this except to blame the mighty climate change, the usual? The worry should be what we do as a people and as a country in the tropical coast.

[46] Expert 46 (in Owerri) - Academic: I have discussed this with topic with many friends today. It appears we no longer have dry season. Let us pray the Oguta experience does not extend to other experiences.

[47] Expert 47 (in Uyo) - Academic: We may likely experience food insecurity.

[48] Expert 48 (in Owerri) - Academic: climate change! The fruit trees are not flowering they are confused. Mango trees especially very few are flowering. There will be fruits scarcity next year.

[49] Expert 49 (in Umuahia) - National Agriculture Seeds Council: Climate change, please advice us. Do we start farming against 2014.

[50] Expert 50 (in Ehime Mbano) - Religious Leader: Haven been exposed to international seminars etc on climate change, I think you are in a better position to advice us on the recent development. On the spiritual plane, I think it is a sign of the end time or an approaching famine.

[51] Expert 51 (in Ehime Mbano) - Religious Leader: You know better but I guess it may cause harmattan and longer dry weather in 2014. You are the expert on climate change. Direct us on what to do.

[52] Expert 52 (in Umuahia) - Academic: You are right. Certainly there will be shorter period of dry season which may favour dry season farming. However fruiting of tree crops may be adversely affected.

[53] Expert 53 (in Ihitte/Uboma) - Religious Leader: It is the effect of climate c change. It rained for five hours here. We have been cautious of flooding this December.

[54] Expert 54 (in Aba) - Business Man: Could be climate change. May likely flood Oguta and other areas.

[55] Expert 55 (in Owerri) - Academic: Global warming and consequences are real.

[56] Expert 56 (in Owerri) - Academic: Never seen such before. Reminding one of Noah's ark! Consequences are late rains next year. Irregular rain pattern again next year. Poor harvest next year, especially fruits. Very likely, unusually high temperature first quarter next year. More insect pests. I wish tenants on earth luck! 
[57] Expert 57 (in Asaba) - Academic: Only God can answer the question. I have been in Agbor, we have not had heavy rains, but it's been cloudy for about $5-7$ days now. We have had showers. That is climate change for you.

[58] Expert 58 (in Zaria) - Academic: Our changing climate. Trust in God.

[59] Expert 59 (in Owerri) - Academic: Snow was scanty at this time last year. Snow has covered more than $60 \%$ of the United States already. Climate change is real.

[60] Expert 60 (in Ibadan) - Non-Governmental Organization: Good for the records. A veritable event to cite in confirming climate change.

[61] Expert 61 (in Owerri) - Academic: Climate change of course. I see the dry season starting late and lasting up till April because the rain is not ceasing now. Smallholder agriculture is in trouble for next season. Dry season vegetable production here will benefit from this pattern of rainfall.

[62] Expert 62 (in Uyo) - Academic: I anticipate an unusual spell of dry season in the first quarter of 2015 or delayed commencement of rains.

[63] Expert 63 (in Owerri) - Academic: From the point of a crop scientist I envisage change in photoperiod which is going to be a limiting factor to the establishment and performance of flowering plants reproduction. Which is an indication that next cropping season will witness low output.

[64] Expert 64 (in Umuahia) - Religious Leader: The seeming regular rainfall in the month of December is viscously suggestive. Harmattan was expected since November. Instead we have the rain. There will be food scarcity next year particularly fruits. Again building materials, especially sharp sand will be scarce because the river volume will increase making it difficult for sand excavators to supply sand. Finally, erosion-prone areas may be in very bad shape. These are likely consequences.

[65] Expert 65 (in Owerri) - Academic: The factors may be many, possibly geographic, but majorly climate change. The consequence will be shortage of food in the coming year because farmers will be misled by sudden appearance of rainfall. Roads also get worse. There is danger in the air.

\section{The Challenge of Climate Change}

Many of the respondents above believed that the extreme rainfall event in Southeast Nigeria December 2013 is attributed to climate change. We therefore examine this further. What is presented her is taken from an inaugural lecture at the Imo State University Owerri titled "Does Agriculture have a future in Southeast Nigeria? (Nwajiuba, 2012)" From studies conducted in "Building Nigeria's Response to Climate Change" (BNRCC), a CIDA-funded project implemented in Nigeria by the Nigerian Environmental Study-Action Team (NEST), changes are expected in Nigeria's climate scenarios till 2100 (Babatunde et al., 2011; BNRCC and Federal Ministry of Environment, 2011). Some of these changes are already happening. In southeast Nigeria which is mostly rainforest, the projection is rising temperature, increased rainfall volume for most parts, increased variability in rainfall regime manifesting as changes in the dates of commencement and cessation of rainfall, and increased frequency of extreme rainfall events such as storms and floods (Babatunde et al., 2011; BNRCC and Federal Ministry of Environment, 2011; NEST, 2011). The future climate expectation for Nigeria is summarized in Table 4. 
Table 4: Summary of Key Trends in Climate Parameters for Nigeria, by Ecological Zone

\begin{tabular}{|l|l|l|l|l|}
\hline \multicolumn{1}{|c|}{ Climate variables } & \multicolumn{1}{|c|}{$\begin{array}{c}\text { Mangrove } \\
\text { zone }\end{array}$} & $\begin{array}{c}\text { Rain } \\
\text { forest }\end{array}$ & \multicolumn{1}{c|}{$\begin{array}{c}\text { Tall grass } \\
\text { (Savanna) }\end{array}$} & $\begin{array}{c}\text { Short grass } \\
\text { (Sahel) }\end{array}$ \\
\hline Temperature & $\uparrow$ & $\uparrow$ & $\uparrow$ & $\uparrow$ \\
\hline Rainfall amount & $\uparrow$ & $\uparrow$ & $\downarrow$ & $\downarrow$ \\
\hline Rainfall variability & $\uparrow$ & $\uparrow$ & $\uparrow$ & $\uparrow$ \\
\hline $\begin{array}{l}\text { Extreme rainfall events:- } \\
\text { droughts }\end{array}$ & Likely & Likely & $\uparrow$ & $\uparrow$ \\
\hline $\begin{array}{l}\text { Extreme rainfall events:- } \\
\text { storms, floods }\end{array}$ & $\uparrow$ & $\uparrow$ & Likely & Likely \\
\hline Sea level rise & $\uparrow$ & NA & NA & NA \\
\hline
\end{tabular}

Legend: $\uparrow$ likely increase or increase; $\downarrow$ likely decrease or decrease; NA not applicable

Source: BNRCC and Federal Ministry of Environment (2011).

The impacts of these include higher temperatures which result in decreased agricultural productivity and production, high evaporation rate (Onyeneke, 2010; Onyeneke et al., 2017) and reduced soil moisture, lowering of the groundwater table, and shrinking of surface water. Heat stress reduces human labour use on farms, lowers labour productivity, and leads to rapid deterioration and wastage of farm produce. Changes in the amount of rain, increased rainfall intensity and changes in rainfall patterns lead to decreased agricultural productivity and production (crops and livestock) (FMARD, 2014; NEST and Tegler, 2011; Nwajiuba et al., 2011). Changing and erratic rainfall patterns make it difficult for farmers to plan their operations, may reduce the cropping season, and can lead to low germination, as well as lead to reduced yield and crop failure. Erratic weather interferes with processing of produce (e.g. sun-drying of crops and smoking of fish). Increased frequency of major storms causes damage to farm land, crops and livestock. Major storms can also cause road wash-outs, which make it difficult to access farms and to market products. Further details of these are to be found in the Climate Change Adaptation Strategy Technical Report (CCASTR) (NEST and Tegler, 2011).

\section{Conclusion}

This work has yielded some lessons. These include the absence of reliable regular and institutionalised measurement of climate parameters in Imo state. There are also gaps in knowledge as regards changing climate parameters and their effect on crop production.

The phenomenon observed so far are similar to the pattern in 1983. Assuming all other variables which impact food crops are equal, the scenario in the years immediately following 1983 offers some lessons for what may follow. This however requires further investigation.

Experts and other stakeholders hold a wide diversity of views on the likely consequences of the extreme rainfall events in December 2013. These views range from those affecting the environment, changing microbial and physical characteristics of the soil. These also affect other sectors besides agriculture including construction.

Crop production could also be affected through pests and diseases which emerge. Human consequences of these changes are not yet clear. 


\section{References}

[1] Babatunde, J.A., Salami, A.T., \& Tadross, M. (2011). Climate Change Scenarios for Nigeria: Understanding Biophysical Impacts. - Climate Systems Analysis Group, Cape Town, for Building Nigeria's Response to Climate Change Project. Ibadan, Nigeria: Nigerian Environmental Study/Action Team (NEST).

[2] Building Nigeria's Response to Climate Change (BNRCC) \& Federal Ministry of Environment (2011). National Adaptation Strategy and Plan of Action on Climate Change for Nigeria (NASPA$\mathrm{CCN}$ ).

[3] Federal Ministry of Agriculture and Rural Development (FMARD) (2014). National Agricultural Resilience Framework. A Report by the Presidential Advisory Committee on Agricultural Resilience in Nigeria.

[4] ISADAP (2008). Imo State Accelerated Development Area Programme (ISADAP) Resource Centre

[5] Nigerian Environmental Study/Action Team (2011). Reports of Research Projects on Impacts and Adaptation. Building Nigeria's Response to Climate Change (BNRCC). Ibadan, Nigeria: Nigerian Environmental Study/Action Team (NEST).

[6] Nigerian Environmental Study Action Team \& Tegler, B. (2011). Climate Change Adaptation Strategy Technical Reports - Nigeria, (CCASTR). Building Nigeria's Response to Climate Change. Ibadan, Nigeria: Nigerian Environmental Study/Action Team (NEST).

[7] Nwajiuba, C.U. (2012). Does Agriculture Have a Future In Southeast Nigeria? Imo State University, Owerri, Nigeria. Inaugural Lecture Series No. 5. Imo State University Owerri.

[8] Nwajiuba, C.U., Onyeneke, R.U., \& Yakubu, A.A., (2011). Climate Change Adaptation Strategy Technical Report for Nigeria: Agriculture Sector. A Compendium of Studies Commissioned and Published by Building Nigeria's Response to Climate Change (BNRCC) Project Coordinated by the Nigerian Environmental Study/Action Team (NEST) 1 Oluokun Street, Off Awolowo Avenue, Bodija UI-P.O Box 22025 Ibadan, Oyo State, Nigeria

[9] Onyeneke R.U. (2010). Climate Change and Crop Farmers' Adaptation Measures in the Southeast Rainforest Zone of Nigeria. M.Sc. Thesis, Department of Agricultural Economics, Extension and Rural Development, Imo State University, Owerri.

[10] Onyeneke, R.U., Mmagu, C.J., \& Aligbe, J.O. (2017): Crop Farmers' Understanding of Climate Change and Adaptation Practices in southeast Nigeria. - World Review of Science, Technology and Sustainable Development 13(4): 299-318.

*Corresponding author.

E-mail address: robertonyeneke@ yahoo.com/robert.onyeneke@ funai.edu.ng 